\title{
Sciendo
}

\section{VARIABILITY OF OTOLITH MORPHOLOGY AND MORPHOMETRY IN EIGHT JUVENILE FISH SPECIES IN THE COASTAL EASTERN ADRIATIC}

\author{
Josipa Ferri*, Karmen Bartulin, Frane Škeljo \\ University of Split, University Department of Marine Studies, Ruđera Boškovića 37, PO Box 190, 21000 Split \\ *Corresponding Author, Email: josipa.ferri@unist.hr
}

\section{ARTICLE INFO}

Received: 5 June 2017

Received in revised form: 23 May 2018

Accepted: 28 May 2018

Online first: 4 July 2018

\begin{abstract}
Sagittae otoliths of eight juvenile species: Boops boops, Diplodus vulgaris, Diplodus puntazzo, Sarpa salpa (family Sparidae), Liza ramada, Liza aurata (family Mugilidae), Atherina boyeri, Atherina hepsetus (family Atherinidae) were analysed and compared using descriptive morphological characters and morphometric indices. The noticeable differences among the otoliths of the investigated species are in their overall shape, margins (i.e. irregular, sinuate or crenate) and anterior region. Otolith shape varied from elliptic to pentagonal in sparids, elliptic to rectangular in mugilids and elliptic in two atherinids. Aspect ratio $\left(\mathrm{O}_{\mathrm{w}} / \mathrm{O}_{\mathrm{L}}\right)$, ratio of the sulcus length occupied by the cauda length $\left(C_{L} / S_{L}\right)$ and ratio of the sulcus length occupied by the ostium length $\left(\mathrm{OS}_{L} / S_{L}\right)$ were calculated for all species. The otolith contour was described using wavelets. The Canonical Analysis of Principal Coordinates (CAP) gave an overview of the otolith shape differentiation between eight juveniles. Using the Wavelet coefficients, the first principal component (CAP1) explained $58.1 \%$ of the variation among species and the second principal component (CAP2) 25.2\%.
\end{abstract}

Keywords:

Otolith

Shape

Size

Juveniles
Ferri, J., Bartulin, K., Škeljo, F. (2018): Variability of otolith morphology and morphometry in eight juvenile fish species in the coastal eastern Adriatic. Croatian Journal of Fisheries, 76, 91-98. DOI: 10.2478/cjf-2018-0012.

\section{INTRODUCTION}

The saccular otoliths (sagittae) display high specific interand intra-variability in shape and size. Therefore, they have been used as efficient tool for the identification of fish species (Tuset et al., 2008; Škeljo and Ferri, 2011; Bani et al., 2013; Jawad et al., 2017a), populations (Bose et al., 2017) and stocks (Mendoza, 2006; Pothin et al., 2006; DuarteNeto et al., 2008). Otoliths have been also applied in studies regarding ontogenetic processes (Capoccioni et al., 2011), spatial and temporal migrations (Smith and Kwak, 2014) and fish age (Mendoza, 2006; Škeljo et al., 2015), which has strong implications in fishery science and management (Vasconcelos et al., 2018). Although the morphological variability is influenced by genetic factors (Vignon and Morat, 2010), exogenous factors such as depth (Lombarte and Lleonart, 1993), water temperature (Lombarte and Lleonart, 1993; Hüssy, 2008), salinity (Capoccioni et al., 2011) and food supply (Gagliano and McCormick, 2004; Hüssy, 2008) also play a strong role in the otolith reshape (Vignon, 2012; Bremm and Schulz, 2014).

Given the importance and scientific relevance of the otoliths, the present study focuses on otolith morphology and morphometry in juveniles of eight fish species, 
belonging to 5 genera and 3 families that are ecologically an important part of the fish assemblages in the coastal eastern Adriatic areas (Dulčić et al., 2004). Sagittae otoliths in adults of the investigated species have been studied in otolith atlases (Campana, 2004; Tuset et al., 2008) and the online otolith database AFORO (Lombarte et al., 2006) but data about otoliths in juveniles is still scarce. In general, juvenile otoliths tend to be relatively featureless, spherical or smoothly oblate in most species (Campana, 2004), so as a result the diagnostic value of these structures is often low. However, considering the consequence of ontogenetic effects on otolith shape variability (Capoccioni et al., 2011), it is important to analyse the otolith shape and size in both juveniles and adults when applying results from numerous otolith studies in fisheries science.

Therefore, two specific objectives are set out: (i) general description of the otoliths of juveniles and (ii) morphometric and contour analyses of otoliths, as steps toward facilitated identification and separation of species. All presented results, including otolith images from the juveniles and Wavelet coefficients, can be an important aid in taxonomic, phylogenetic, palaeoichthyological and dietary studies.

\section{MATERIALS AND METHODS}

The juveniles of eight species belonging to the families Sparidae, Mugilidae and Atherinidae were collected in March 2013 and June 2014. A total of 130 specimens were caught on two localities in the coastal shallow waters in the eastern

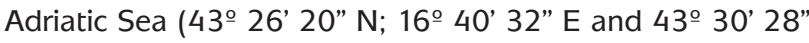
$\left.\mathrm{N} ; 6^{\circ} 22^{\prime} 57^{\prime \prime} \mathrm{E}\right)$, using a beach seine (mesh size $4 \mathrm{~mm}$ ). Fish species were identified based on the morphological and meristic characteristics (Jardas, 1996; Froese and Pauly, 2017). For each fish, total length $\left(L_{T}\right)$ was measured to the nearest $1 \mathrm{~mm}$, body weight (W) to the nearest $0.1 \mathrm{~g}$ and the sagittae otolith pairs were removed, cleaned with distilled water and stored dry for later examination. Size ranges of all investigated juveniles are presented in Table 1.

Otoliths were described using the terminology proposed by Tuset et al. (2008). They were photographed using a stereo microscope with an Olympus DP-25 digital camera attached. Otoliths were positioned with their rostrum to the left and images were taken on a black background in order to achieve good light contrast. Five morphometrical features were measured to the nearest $0.01 \mathrm{~mm}$ using Olympus cell^$\wedge^{\wedge}$ Imaging Software: otolith length $\left(\mathrm{O}_{\mathrm{L}}\right)$, otolith width $\left(O_{w}\right)$, sulcus length $\left(S_{L}\right)$, cauda length $\left(C_{L}\right)$ and ostium length $\left(\mathrm{OS}_{L}\right)$. Otolith mass $\left(\mathrm{O}_{M}\right)$ was weighed to the nearest 0.0001 $g$. Differences between left and right otoliths were tested by paired $t$ test. Three shape indices were also estimated: aspect ratio $\left(\mathrm{O}_{\mathrm{W}} / \mathrm{O}_{\mathrm{L}} ; \%\right)$, ratio of the sulcus length occupied by the cauda length $\left(\mathrm{C}_{\mathrm{L}} / \mathrm{S}_{\mathrm{L}} ; \%\right)$ and ratio of the sulcus length occupied by the ostium length $\left(\mathrm{OS}_{\mathrm{L}} / \mathrm{S}_{\mathrm{L}} ; \%\right)$. Moreover, the
Table 1. Range of fish total length $\left(L_{T}\right)$ and body weight (W) and number of individuals ( $n$ ) of eight juvenile species analysed in this study (length in $\mathrm{mm}$, weight in $g$ ). Mean \pm standard deviation is given in parentheses..

\begin{tabular}{lccc}
\hline \hline & $\mathbf{n}$ & $\mathbf{L}_{\mathrm{T}}$ & $\mathbf{W}$ \\
\hline Boops boops & 6 & $45-60$ & $1.10-2.80$ \\
& & $(55 \pm 0.63)$ & $(1.99 \pm 0.60)$ \\
Diplodus vulgaris & 16 & $30-115$ & $0.49-29.20$ \\
& & $(65 \pm 3.30)$ & $(8.38 \pm 10.11)$ \\
Diplodus puntazzo & 6 & $35-45$ & $0.76-1.45$ \\
& & $(39 \pm 0.37)$ & $(1.02 \pm 0.22)$ \\
Sarpa salpa & \multirow{2}{*}{11} & $40-60$ & $0.97-1.34$ \\
Liza ramada & & $(45 \pm 0.26)$ & $(1.16 \pm 0.12)$ \\
& \multirow{2}{*}{31} & $20-30$ & $0.07-0.19$ \\
Liza aurata & & $(25 \pm 0.22)$ & $(0.10 \pm 0.02)$ \\
& 21 & $41-60$ & $0.56-1.89$ \\
Atherina boyeri & \multirow{2}{*}{11} & $(51 \pm 0.41)$ & $(1.09 \pm 0.31)$ \\
& & $(66 \pm 0.54)$ & $(1.74 \pm 0.60)$ \\
Atherina hepsetus & 28 & $30-70$ & $0.13-2.28$ \\
& & $(45 \pm 0.48)$ & $(0.74 \pm 0.42)$ \\
\hline \hline
\end{tabular}

otolith contour was analysed using wavelets (Graps, 1995), using the ShapeR software package (Libungan and Pálsson, 2015a) in the programming language R ( $R$ Core Team, 2014). The analysis was performed following the procedure described by Libungan and Pálsson (2015b): otolith outlines were automatically extracted from the images by the intensity thresholding (bright otolith against a dark background), and smoothed in order to eliminate pixel noise by calculating a weighted moving average over three successive coordinate points. After, they were automatically rotated and positioned horizontally along the longest axis of the otoliths, centred based on their centroid (the mean of the $x$ and $y$ coordinates of the outline), and their area was set equal in all (area $=1$ ). In this way the otolith size and position and rotation during the photographing are standardized, allowing for unbiased comparison of their outline shape. When all the outlines were standardized in this way, they were transformed into 64 independent wavelet shape coefficients using Discrete Wavelet Transform. Initial point of the Wavelet analysis was the posterior margin of the otolith, to which $0^{\circ}$ angle was designated, and it proceeded counterclockwise towards $360^{\circ}$ angle (Fig. 1A). The shape coefficients were standardized with fish length in order to adjust for allometric relationships. Coefficients which showed significant interaction $(\mathrm{P}<0.05)$ between species and fish length were discarded. Remaining Wavelet coefficients were used to analyse the variation in shape among the species by ANOVA 
like permutation test (Libungan and Pálsson, 2015b), followed by the Canonical Analysis of Principal Coordinates (CAP) (Anderson and Willis, 2003), both performed using the vegan package (Oksanen et al., 2013). In order to estimate whether the otolith shape can be used to predict which species it belongs to, a linear discriminant analysis (LDA) was performed on the Wavelet coefficients, using the leave-one-out cross-validation procedure in the MASS package (Venables and Ripley, 2002). The cross-validation procedure omits each observation one at a time, calculates the classification function using the remaining data, and then classifies the omitted observation. Based on the LDA, both overall and species-specific classification results are provided, allowing us to assess the use of otolith shape in species identification.

\section{RESULTS}

\section{Morphologic variability}

The shape of the otoliths in Boops boops, Sarpa salpa, Liza aurata, Atherina boyeri and Atherina hepsetus is elliptic, while they are pentagonal to elliptic in two Diplodus species and elliptic to rectangular in Liza ramada (Fig. 1A$\mathrm{H})$. Margins and anterior region are very variable in the otoliths of analysed species and may help to differentiate juveniles. Margins varied between regular in otoliths of $A$. hepsetus to irregular in otoliths of all other species (Fig. 1A$\mathrm{H})$. Irregularities such as sinuate to crenate margins were observed in Diplodus species, serrate margins in S. salpa, and crenate margins in $L$. aurata and $A$. boyeri. The anterior region in the otoliths, with rostrum and antirostrum in most juveniles, is changeable between peaked and round. The broad rostrum was characteristic in otoliths of the sparids, while peaked rostrum was observed in two atherinids. The antirostrum was always shorter than the rostrum and it varied in shape between complete absences or poorly developed or short and broad in otoliths of juveniles (Fig. 1A$H$ ). The ostium and sulcus acusticus in otoliths of all species were characterized to be funnel-like and heterosulcoid, respectively. On the other side, in otoliths of sparids, the cauda was posteriorly slightly curved, while it was tubular in Liza species and either tubular or straight in two Atherina species.

\section{Morphometric variability}

No significant differences in morphometric measures were found between left and right otoliths (paired $t$ test, $\mathrm{P}>$ 0.05 for all measures), so mean values for each otolith pair were used in analyses. Otolith measures and values of all calculated indices of all investigated juveniles are presented in Table 2 and Table 3, respectively.

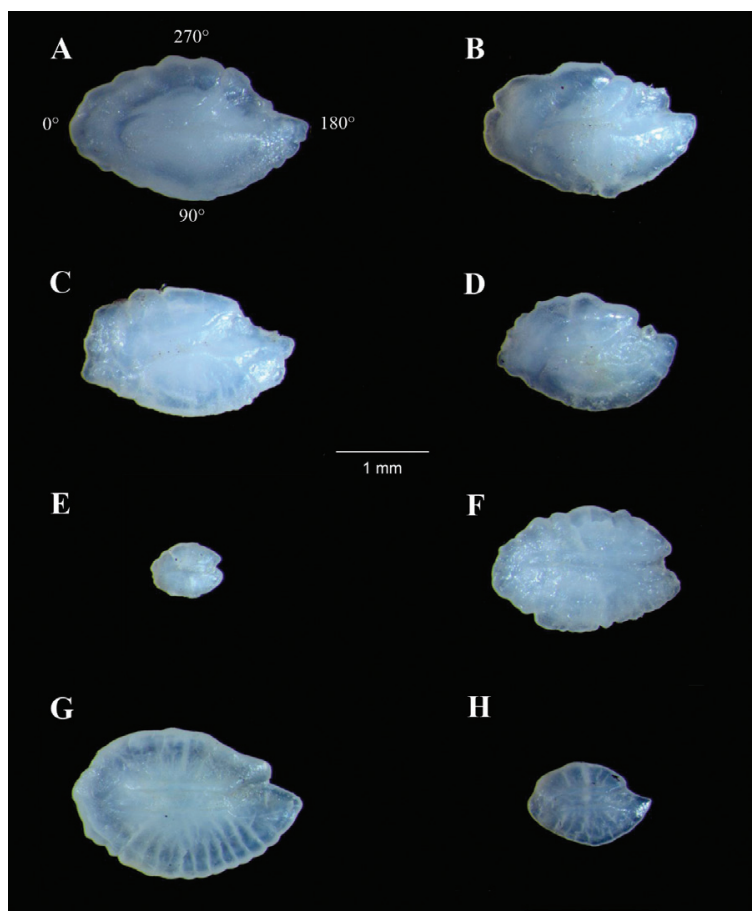

Fig 1. Otolith morphology of Boops boops (A), Diplodus vulgaris (B), Diplodus puntazzo (C), Sarpa salpa (D), Liza ramada $(\mathrm{E})$, Liza aurata $(\mathrm{F})$, Atherina boyeri $(\mathrm{G})$ and Atherina hepsetus $(\mathrm{H})$ (the left otolith with anterior region to the right and dorsal margin to the top).

\section{Contour variability}

From the 64 independent wavelet shape coefficients produced by the Discrete Wavelet Transform, 6 showed significant interaction between species and fish length, and were discarded. Remaining 58 Wavelet coefficients were used to analyse the variation in shape among the species. Most of the variation among investigated species can be traced to single otolith area, at $180^{\circ}$ angle of the otolith outline (Fig. 2) which corresponds roughly to the anterior region (rostrum).

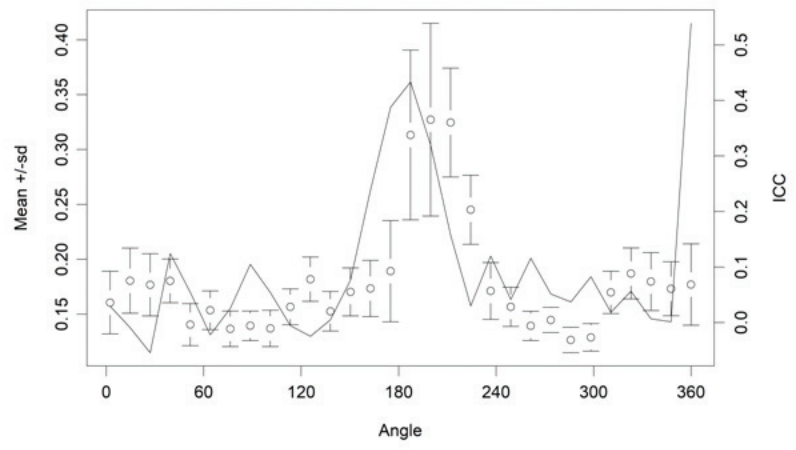

Fig 2. Mean and standard deviation (sd) of the Wavelet coefficients for all combined otoliths and the proportion of variance among eight juvenile species or the intraclass correlation (ICC; black solid line). The horizontal axis shows angle in degrees $\left({ }^{\circ}\right)$, with angles 0 and 180 corresponding roughly to posterior and anterior region, respectively (Fig. 1A). 
Table 2. Range of otolith length $\left(\mathrm{O}_{L}\right)$, otolith width $\left(\mathrm{O}_{W}\right)$, otolith mass $\left(\mathrm{O}_{M}\right)$, sulcus length $\left(S_{L}\right)$, cauda length $\left(C_{L}\right)$ and ostium length $\left(O S_{L}\right)$ of eight juvenile species analysed in this study (lengths, width in $\mathrm{mm}$, mass in $g$ ). Mean \pm standard deviation is given in parentheses.

\begin{tabular}{lcccccc}
\hline \hline & $\mathrm{O}_{\mathrm{L}}$ & $\mathrm{O}_{\mathrm{w}}$ & $\mathrm{O}_{\mathrm{M}}$ & $\mathrm{S}_{\mathrm{L}}$ & $\mathrm{C}_{\mathrm{L}}$ & $\mathrm{OS}_{\mathrm{L}}$ \\
\hline Boops boops & $1.93-2.88$ & $1.20-1.70$ & $0.0009-0.0029$ & $1.34-1.69$ & $0.73-0.92$ & $0.42-0.84$ \\
& $(2.52 \pm 0.37)$ & $(1.50 \pm 0.19)$ & $(0.0020 \pm 0.0007)$ & $(1.47 \pm 0.16)$ & $(0.83 \pm 0.08)$ & $(0.64 \pm 0.17)$ \\
Diplodus & $1.52-4.59$ & $1.03-2.70$ & $0.0008-0.0100$ & $0.92-1.19$ & $0.54-0.63$ & $0.33-0.58$ \\
vulgaris & $(2.70 \pm 1.01)$ & $(1.68 \pm 0.63)$ & $(0.0039 \pm 0.0037)$ & $(1.01 \pm 0.13)$ & $(0.59 \pm 0.04)$ & $(0.41 \pm 0.11)$ \\
Diplodus & $2.02-2.38$ & $1.33-1.45$ & $0.0013-0.0017$ & $1.14-1.22$ & $0.67-0.71$ & $0.45-0.55$ \\
puntazzo & $(2.17 \pm 0.12)$ & $(1.37 \pm 0.04)$ & $(0.0015 \pm 0.0001)$ & $(1.18 \pm 0.04)$ & $(0.69 \pm 0.02)$ & $(0.49 \pm 0.06)$ \\
& $1.92-2.19$ & $1.21-1.44$ & $0.0008-0.0049$ & $0.78-1.07$ & $0.40-0.56$ & $0.38-0.51$ \\
Sarpa salpa & $(2.04 \pm 0.09)$ & $(1.31 \pm 0.07)$ & $(0.0013 \pm 0.0010)$ & $(0.99 \pm 0.11)$ & $(0.51 \pm 0.06)$ & $(0.48 \pm 0.05)$ \\
& $0.66-1.26$ & $0.49-0.92$ & $0.0001-0.0001$ & $0.40-0.44$ & $0.21-0.26$ & $0.18-0.21$ \\
Liza ramada & $(0.82 \pm 0.10)$ & $(0.62 \pm 0.07)$ & $(0.0001 \pm 0)$ & $(0.42 \pm 0.02)$ & $(0.23 \pm 0.02)$ & $(0.19 \pm 0.01)$ \\
& $1.69-2.28$ & $0.99-1.38$ & $0.0007-0.0019$ & $1.33-1.68$ & $0.74-1.03$ & $0.58-0.66$ \\
Liza aurata & $(1.96 \pm 0.13)$ & $(1.23 \pm 0.08)$ & $(0.0012 \pm 0.0003)$ & $(1.50 \pm 0.16)$ & $(0.89 \pm 0.13)$ & $(0.60 \pm 0.03)$ \\
Atherina & $2.26-2.78$ & $1.45-1.97$ & $0.0020-0.0040$ & $1.49-1.81$ & $0.83-0.96$ & $0.55-0.87$ \\
boyeri & $(2.56 \pm 0.16)$ & $(1.69 \pm 0.15)$ & $(0.0020 \pm 0.0006)$ & $(1.61 \pm 0.15)$ & $(0.90 \pm 0.06)$ & $(0.71 \pm 0.14)$ \\
Atherina & $1.04-2.87$ & $0.66-1.88$ & $0.0001-0.0037$ & $0.63-1.08$ & $0.44-0.61$ & $0.19-0.48$ \\
hepsetus & $(1.51 \pm 0.38)$ & $(1.01 \pm 0.27)$ & $(0.0006 \pm 0.0008)$ & $(0.80 \pm 0.18)$ & $(0.53 \pm 0.09)$ & $(0.27 \pm 0.12)$ \\
\hline \hline
\end{tabular}

Table 3. Range of aspect ratio $\left(\mathrm{O}_{\mathrm{w}} / \mathrm{O}_{\mathrm{L}} ; \%\right)$, ratio of the sulcus length occupied by the cauda length $\left(\mathrm{C}_{\mathrm{L}} /\right.$ $\left.\mathrm{S}_{\mathrm{L}} ; \%\right)$ and ratio of the sulcus length occupied by the ostium length $\left(\mathrm{OS}_{\mathrm{L}} / \mathrm{S}_{\mathrm{L}} ; \%\right)$ of eight juvenile species analysed in this study.

\begin{tabular}{lccc}
\hline \hline & $\mathrm{O}_{\mathrm{w}} / \mathrm{O}_{\mathrm{L}}$ & $\mathrm{C}_{\mathrm{L}} / \mathrm{S}_{\mathrm{L}}$ & $\mathrm{C}_{\mathrm{L}} / \mathrm{S}_{\mathrm{L}}$ \\
\hline Boops boops & $58.3-62.2$ & $50.5-68.8$ & $31.3-49.5$ \\
Diplodus vulgaris & $57.6-67.4$ & $51.7-65.5$ & $34.5-48.3$ \\
Diplodus puntazzo & $60.9-66.2$ & $54.9-60.8$ & $39.2-45.2$ \\
Sarpa salpa & $60.5-68.9$ & $50.3-52.3$ & $47.7-49.7$ \\
Liza ramada & $67.3-86.4$ & $52.8-59.4$ & $40.7-47.2$ \\
Liza aurata & $58.3-67.4$ & $56.1-62.9$ & $37.1-43.9$ \\
Atherina boyeri & $59.7-74.6$ & $36.4-47.8$ & $52.2-63.6$ \\
Atherina hepsetus & $60.6-70.9$ & $55.2-73.4$ & $26.6-44.8$ \\
\hline \hline
\end{tabular}

Since significant differences in the otolith shape of analysed species were found by ANOVA-like permutation test $(\mathrm{P}<$ 0.001 , differences were tested by 1000 permutations), CAP was performed and the percentage of variance explained by each principal component is given in Table 4 . The first principal component (CAP 1 ) explained $58.1 \%$ of the variation among species and the second principal component (CAP2) $25.2 \%$ (Fig. 3). Two mugilids and $A$. boyeri differed from four sparids and $A$. hepsetus along the CAP1 and $L$. aurata and $A$. boyeri showed deviation from the other species along the CAP2. The overall classification success for 8 analysed

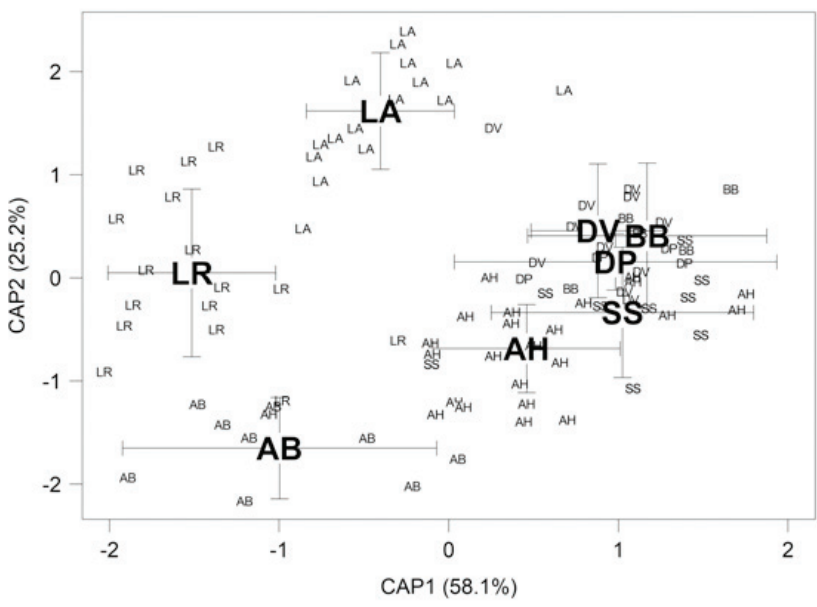

Fig 3. Otolith shape of eight juvenile species using Canonical Analysis of Principal Coordinates with the Wavelet coefficients. Bigger letters represent the mean canonical value for each species and smaller letters represent individual fish: Boops boops (BB), Diplodus vulgaris (DV), Diplodus puntazzo (DP), Sarpa salpa (SS), Liza ramada (LR), Liza aurata (LA), Atherina boyeri (AB) and Atherina hepsetus (AH). Interval surrounding the mean canonical values represent $95 \%$ confidence interval.

species based on the LDA with cross-validation procedure was $\mathbf{8 0 . 8 \%}$. Species-specific classification success ranged from $45.5 \%$ for $D$. vulgaris to $100.0 \%$ for $B$. boops (Table 5 ). . 
Table 4. Variance explained by principal components (CAPn).

\begin{tabular}{lll}
\hline \hline Component & Proportion of variance (\%) & Cumulative proportion of variance (\%) \\
\hline CAP1 & 58.1 & 58.1 \\
CAP2 & 25.2 & 83.3 \\
CAP3 & 7.3 & 90.6 \\
CAP4 & 5.9 & 96.5 \\
CAP5 & 1.5 & 98.0 \\
CAP6 & 1.1 & 99.1 \\
CAP7 & 0.9 & 100.0 \\
\hline \hline
\end{tabular}

Table 5. Cross-validated classification matrix of linear discriminant analysis between analysed species (Atherina boyeri AB, Atherina hepsetus AH, Boops boops BB, Diplodus puntazzo DP, Diplodus vulgaris DV, Liza aurata LA, Liza ramada LR, Sarpa salpa SS) based on Wavelet coefficients. Values are percentages of specimens of actual species (given in rows) that were classified as the species given in columns. Percentages of correctly classified specimens for each species are underlined.

\begin{tabular}{lcccccccc}
\hline \hline \multirow{2}{*}{ Actual species } & \multicolumn{8}{c}{ Classification by otolith shape } \\
& AB & AH & BB & DP & DV & LA & LR & SS \\
\hline AB & $\underline{88.9}$ & 11.1 & 0 & 0 & 0 & 0 & 0 & 0 \\
AH & 4.2 & $\underline{91.7}$ & 0 & 0 & 0 & 0 & 0 & 4.2 \\
BB & 0 & 0 & $\underline{100.0}$ & 0 & 0 & 0 & 0 & 0 \\
DP & 0 & 25 & 0 & $\underline{50}$ & 0 & 0 & 0 & 25 \\
DV & 0 & 18.2 & 18.2 & 9.1 & $\underline{45.5}$ & 0 & 0 & 9.1 \\
LA & 0 & 0 & 0 & 0 & 0 & $\underline{93.8}$ & 6.2 & 0 \\
LR & 6.2 & 6.2 & 0 & 0 & 0 & 6.2 & $\underline{81.2}$ & 0 \\
SS & 0 & 11.1 & 0 & 11.1 & 11.1 & 0 & 0 & $\underline{66.7}$ \\
\hline \hline
\end{tabular}

\section{DISCUSSION}

TThe results indicate that otolith morphology presents a useful and informative character for identification and discrimination of the analysed species. The observed variations in sagittae shape, margins and anterior region among the studied juveniles prove that otoliths are species-specific. Overall morphology varied from elliptic to pentagonal in sparids, elliptic to rectangular, with a notch between rostrum and antirostrum in mugilids and elliptic, with round posterior zone in two Atherina species. Considering morphologic variability between ostium and cauda, caudal region seems to be more discriminant than ostium: the ostium is generally funnel-like and shorter than the cauda in all juveniles and the cauda is generally tubular and straight or more or less curved towards posterior otolith region. According to numerous studies, observed variations may be due to the differences in the habitat, preferred depth, availability of food, hearing ability (variability of the sensorial macula) and behaviour of the species (Lombarte, 1992; Paxton, 2000; Volpedo and Echevarría, 2003; Cruz and Lombarte, 2004; Montanini et al., 2015; Jawad et al., 2017b). Further investigations of the ecology of studied juveniles are needed to prove and explain possible effects of diverse environmental factors on their otolith morphology.

In comparison with available published morphologic descriptions of sagittae otoliths of adult species, the differences in otolith shape, outline, margins and regions of ostium and cauda between juveniles and adults were analysed. Comparison revealed that distinctive characteristics of the otoliths in the Sparidae adults, such as the presence of wide protuberance in the middle of the dorsal margins in Boops boops, crenate ventral margins in Diplodus vulgaris, irregular outline and margins in Diplodus puntazzo and sharp-end in the posterior otolith zone of Sarpa salpa, as reported by Tuset et al. (2008), were not observed and present in otoliths of juveniles of the same species. In addition, posteriorly strongly flexed cauda was observed only in otoliths of adult mugilids while the anterior dorsal area was strongly developed only in adult Liza aurata otoliths (Tuset et al., 2008). This could be due to the changes in physical and chemical parameters in different habitats, as the life cycle of mugilids involves migrations between freshwater and marine environments (Bartulović et 
al., 2007). In general, all variations between juveniles and adults were primarily observed in otolith outline, margins and sulcus area while its overall shape remained the same in different life stages. However, it should be emphasized that the observed variations, as a part of ontogenetic allometry, could also be due to the different habitats of compared fish species, as Tuset et al. (2008) analysed otoliths of the western Mediterranean and north and central eastern Atlantic fishes.

The ability to identify species using sagittae morphometric indices has been proved for teleosts in general (Tuset et al., 2003; Ponton, 2006; Bani et al., 2013). Evaluation of the calculated ratios confirmed variations in otolith characteristics among analysed species. In addition, aspect ratio values from this study correspond to the data provided for $D$. vulgaris, S. salpa and Atherina boyeri of the similar size (fish total length) on the online otolith database AFORO (Lombarte et al., 2006). In comparison with available values for adult species (Tuset et al., 2008), all juveniles except Liza ramada and $A$. boyeri had narrower ranges of these ratios. The Canonical Analysis of Principal Coordinates suggests that a reasonably high level of separation can be obtained for three species: $L$. aurata, $L$. ramada and $A$. boyeri, while all the other species together form a single group. The Wavelet transform used in this study provides a powerful alternative to the more commonly applied Fourier transform in shape analysis. While the Fourier transform provides functions in the form of sines and cosines, which are non-local and can therefore result in poor approximations of sharp edges, the Wavelet transform uses approximating functions that are contained in finite domains making them well-suited for approximating sharp edges (Libungan and Pálsson, 2015b). The overall data in this study indicates that variations in otolith shape and size could be used as informative characters for identification of the analysed fish species. Moreover, the advantage of using otolith shape analysis in species identification is that they are cost-effective and only require otolith images from which outlines can be extracted and analysed with statistical software.

\section{ACKNOWLEDGEMENTS}

The authors would like to thank the anonymous reviewer for helpful and constructive comments that greatly contributed to improving the manuscript.

\section{SAŽETAK}

\section{VARIJABILNOST MORFOLOGIJE I MORFOMETRIJE OTOLITA NEDORASLIH STADIJA OSAM VRSTA RIBA U PRIOBALNOM ISTOČNOM JADRANU}

Sagitalni otoliti nedoraslih stadija osam vrsta riba: Boops boops, Diplodus vulgaris, Diplodus puntazzo, Sarpa salpa (porodica Sparidae), Liza ramada, Liza aurata (porodica Mugilidae), Atherina boyeri, Atherina hepsetus (porodica Atherinidae) su analizirani i međusobno uspoređeni opisnim morfološkim značajkama te morfometrijskim mjerama. Uočljive razlike među otolitima istraživanih vrsta odnose se na njihov oblik, rub (npr. nepravilan, valovit, pilast) i prednji dio. Oblik otolita je elipsast do pentagonalan kod sparidnih vrsta, elipsast do pravokutan kod cipla te elipsast kod dvije vrste gavuna. Omjeri širine i dužine otolita $\left(\mathrm{O}_{\mathrm{w}} /\right.$ $\left.\mathrm{O}_{\mathrm{L}}\right)$, zatim dužine caude i sulcusa $\left(\mathrm{C}_{\mathrm{L}} / \mathrm{S}_{\mathrm{L}}\right)$ te dužine ostiuma i sulcusa $\left(\mathrm{OS}_{L} / \mathrm{S}_{L}\right)$ su određeni za svaku vrstu. Obris otolita je analiziran Wavelet transformacijom. Analiza glavnih komponenata ukazala je na međusobne razlike u obliku otolita među nedoraslim stadijima osam analiziranih vrsta. Korištenjem Wavelet koeficijenata, prvom komponentom objašnjeno je 58,1\% varijacije među vrstama, a drugom komponentom $25,2 \%$.

Ključne riječi: otolit, oblik, veličina, nedorasli stadiji

\section{REFERENCES}

Anderson, M. J., Willis, T. J. (2003): Canonical analysis of principal coordinates: A useful method of constrained ordination for ecology. Ecology, 84, 511-525.

Bani, A., Poursaeid, S., Tuset, V. M. (2013): Comparative morphology of the sagittal otolith in three species of south Caspian gobies. Journal of Fish Biology, 82, 1321-1332.

Bartulović, V., Glamuzina, B., Lučić, D., Conides, A., Jasprica, N., Dulčić, J. (2007): Recruitment and food composition of juvenile thin-lipped grey mullet, Liza ramada (Risso, 1826), in the Neretva River estuary (Eastern Adriatic, Croatia). Acta Adriatica, 48, 1, 25-37.

Bose, A., Adragna, J., Balshine, S. (2017): Otolith morphology varies between populations, sexes, and male alternative reproductive tactics in a vocal toadfish Porichthys notatus. Journal of Fish Biology, 90, 1, 311-325.

Bremm, C. Q., Schulz, U. H. (2014): Otolith atlas of fish of the Sinos River. Brazilian Journal of Biology, 74, 2, 274-282.

Campana, S. E. (2004): Photographic Atlas of Fish Otoliths of the Northwest Atlantic Ocean. Ottawa (Ontario), NRC Research Press. 284pp.

Capoccioni, F., Costa, C., Aguzzi, J., Menesatti, P., Lombarte, A., Ciccotti, E. (2011): Ontogenetic and environmental effects on otolith shape variability in three Mediterranean European eel (Anguilla anguilla, L.) local stocks. Journal of Experimental Marine Biology and Ecology, 397, 1, 1-7.

Cruz, A., Lombarte, A. (2004): Otolith size and its relationship with colour pattern and sound production. Journal of Fish Biology, 65, 6, 1512-1525.

Duarte-Neto, P., Lessa, R., Stosic, B., Morize, E. (2008): The use of sagittal otoliths in discriminating stocks of common dolphinfish (Coryphaena hippurus) off northeastern 
Brazil using multishape descriptors. Journal of Marine Science, 65, 7, 1144-1152.

Dulčić, J., Fencil, M., Matić-Skoko, S., Kraljević, M., Glamuzina, B. (2004): Diel catch variations in a shallow-water fish assemblage at Duće Glava, eastern Adriatic (Croatian Coast). Journal of the Marine Biological Association of the United Kingdom, 84, 659-664.

Froese, R., Pauly, D. (2017): FishBase. World Wide Web electronic publication. www.fishbase.org, version (10/2017).

Gagliano, M., McCormick, M. I. (2004): Feeding history influences otolith shape in tropical fish. Marine Ecology Progress Series, 278, 291-296.

Graps, A. (1995): An Introduction to Wavelets. IEEE Computational Science \& Engineering, 2, 50-61.

Hüssy, K. (2008): Otolith shape in juvenile cod (Gadus morhua): Ontogenetic and environmental effects. Journal of Experimental Marine Biology and Ecology, 364, 35-41.

Jardas, I. (1996): Jadranska intiofauna. Zagreb, Školska knjiga. 533pp.

Jawad, L. A., Hoedemakers, K., Ibáñez, A., Ahmed, Y., Abu ElRegal, M., Mehanna, S. (2017a): Morphology study of the otoliths of the parrotfish, Chlorurus sordidus (Forsskăl, 1775) and Hipposcarus harid (Forsskål, 1775) from the Red Sea coast of Egypt (Family: Scaridae). Journal of the Marine Biological Association of the United Kingdom, 1-10, doi:10.1017/S0025315416002034.

Jawad, L. A., Sabatino, G., Ibáñez, A. L., Andaloro, F., Battaglia, P. (2017b): Morphology and ontogenetic changes in otoliths of the mesopelagic fishes Ceratoscopelus maderensis (Myctophidae), Vinciguerria attenuata and $V$. poweriae (Phosichthyidae) from the Strait of Messina (Mediterranean Sea). Acta Zoologica, 00, 1-17.

Libungan, L. A., Pálsson, S. (2015a): ShapeR: Collection and Analysis of Otolith Shape Data, version 0.1-5. R package. Available: https://github.com/lisalibungan/shapeR.

Libungan, L. A., Pálsson, S. (2015b): ShapeR: An R Package to Study Otolith Shape Variation among Fish Populations. PLoS ONE 10(3):e0121102; doi:10.1371/ journal.pone.0121102.

Lombarte. A. (1992): Changes in otolith area: sensory area ratio with body size and depth. Environmental Biology of Fishes, 33, 405-410.

Lombarte, A., Lleonart, J. (1993): Otolith size changes related with body growth, habitat depth and temperature. Environmental Biology of Fishes, 37, 297-306.

Lombarte, A., Chic, Ò., Parisi-Baradad, V., Olivella, R., Piera, J., García-Ladona, E. (2006): A web-based environment from shape analysis of fish otoliths. The AFORO database. Scientia Marina, 70, 147-152.

Mendoza, R. P. R. (2006): Otoliths and their applications in fishery science. Ribarstvo, 64, 89-102.

Montanini, S., Stagioni, M., Valdrè, G., Tommasini, S.,
Vallisneri M. (2015): Intra-specific and inter-specific variability of the sulcus acusticus of sagittal otoliths in two gurnard species (Scorpaeniformes, Triglidae). Fisheries Research, 161, 93-101.

Oksanen, J., Blanchet, F. G., Kindt, R., Legendre, P., Minchin, P. R., OıHara, R. B., et al. (2013): Vegan: Community Ecology Package, version 2.0-7. R package. Available: http://CRAN.R-project.org/package = vegan.

Paxton, J. R. (2000): Fish otoliths: Do sizes correlate with taxonomic group, habitat and/or luminescence? Philosophical Transactions of the Royal Society of London B, 355, 1401, 1299-1303.

Ponton, D. (2006): Is geometric morphometrics efficient for comparing otolith shape of different fish species? Journal of Morphology, 267, 6, 750-757.

Pothin, K., Gonzalez-Salas, C., Chabanet, P., LecomteFiniger, R. (2006): Distinction between Mulloidichthys flavolineatus juveniles from Reunion Island and Mauritius Island (south-west Indian Ocean) based on otolith morphometrics. Journal of Fish Biology, 69, 38-53.

R Core Team. (2014): R: A language and environment for statistical computing. Vienna, Austria. Available: http:// www.R-project.org/: $\mathrm{R}$ Foundation for Statistical Computing.

Smith, W. E., Kwak, T. J. (2014): A capture-recapture model of amphidromous fish dispersal. Journal of Fish Biology, 84, 897-912.

Škeljo, F., Ferri, J. (2011): The use of otolith shape and morphometry for identification and size-estimation of five wrasse species in predator-prey studies. Journal of Applied Ichthyology, 28, 4, 524-530.

Škeljo, F., Brčić, J., Vuletin, V., Ferri, J. (2015): Age and growth of the axillary wrasse, Symphodus mediterraneus (L.) from the eastern Adriatic Sea. Marine Biology Research, 11, 780-784.

Tuset, V. M., Lombarte, A., González, J. A., Pertusa, J. F., Lorente, M. J. (2003): Comparative morphology of the sagittal otolith in Serranus spp. Journal of Fish Biology, 63, 6, 1491-504.

Tuset, V. M., Lombarte, A., Assis, C. A. (2008): Otolith atlas for the western Mediterranean, north and central eastern Atlantic. Scientia Marina, 72, 7-198.

Vasconcelos, J., Vieira, A. R., Sequeira, V., González, J. A., Kaufmann, M., Serrano Gordo, L. (2018): Identifying populations of the blue jack mackerel (Trachurus picturatus) in the Northeast Atlantic by using geometric morphometrics and otolith shape analysis. Fishery Bulletin, 116, 81-92.

Venables, W. N., Ripley, B. D. (2002): Modern Applied Statistics with S. Fourth Edition. Springer, New York. ISBN 0-387-95457-0.

Vignon, M. (2012): Ontogenetic trajectories of otolith shape during shift in habitat use: Interaction between otolith growth and environment. Journal of Experimental 
Marine Biology and Ecology, 420-421, 26-32.

Vignon, M., Morat, F. (2010): Environmental and genetic determinant of otolith shape revealed by a nonindigenous tropical fish. Marine Ecology Progress Series,
411, 231-241.

Volpedo, A., Echeverría, D. D. (2003): Ecomorphological patterns of the sagitta in fish on the continental shelf off Argentine. Fisheries Research, 60, 2-3, 551-560. 